\title{
Grasses (Poaceae) From Senegal: New Records Checklist, Biogeographical Affinities and Biological Types
}

\author{
Ablaye Ngom, PhD \\ Mame Samba Mbaye, Professor \\ Abdoul Aziz Camara, PhD \\ Madiop Gueye, PhD \\ Kandioura Noba, Professor
}

Laboratory of Botany and Biodiversity, Plant Biology Department,

Cheikh Anta Diop University of Dakar, Senegal

Doi:10.19044/esj.2020.v16n18p177 URL:http://dx.doi.org/10.19044/esj.2020.v16n18p177

\begin{abstract}
Poaceae is one of the most diverse families in Senegal's flora after Fabaceae. It has been the subject of several studies but many species were not taken into account in the evaluation of the current state of its diversity. This paper provides a checklist of new grasses encountered in Senegal. After a detailed scrutiny of the literature and herbarium specimens, we ascertain their identity and report them as new records to the grass flora of Senegal. A total of 24 new species have been listed belonging to 15 genera of which the most represented is Sporobolus with 5 species. The other genera such as Digitaria, Eragrostis, Perotis, Setaria, and Trichanthecium on the one hand and Aristida, Chloris, Cymbopogon, Enteropogon, Leptochloa, Oryza, Panicum, Schizachyrium, Urochloa on the other hand have two and one species respectively. The chorological spectrum shows the dominance of African species (45.83\%) followed by those of Afro-Asian origin (33.33\%). Like the overall flora of Senegal, this new grass flora is of tropical nature with a preponderance of Sudano-Zambesian species (50\%) followed by GuineanCongolese-Sudano-Zambesian species $(29.17 \%)$ at continental scale. Biological types based on the life form shows therophytes $(62.50 \%)$ are predominant, followed by hemicryptophytes (29.17\%) and geophytes (8.33\%). Taking these new data into account would allow a more precise determination of the Senegalese grass flora composition.
\end{abstract}

Keywords: Biodiversity, Flora, Gramineae, Senegal 


\section{Introduction}

Senegal is the most western country of Africa (between $12^{\circ} 8$ and $16^{\circ} 09$ north latitude and $12^{\circ}$ and $17^{\circ}$ west longitude), in a transition zone between the North and the South rainforest, which has a rich ecosystem of high biological diversity (MEPN, 1997; Ngom et al., 2019). The vascular flora of Senegal presents a taxonomic spectrum characteristic of tropical vegetation of the savannah type made up of herbaceous species representing more than $50 \%$. Poaceae form the dominant family with Cyperaceae and Legumes. These families are generally represented by annual grasses adapting to changing mesological conditions (Ba \& Noba, 2001).

The grass flora of Senegal has been the subject of several studies. The most remarkable ones are those of Berhaut (1967), Vanden Berghen (1988), Ba \& Noba (2001) and Mugnier (2008). In the "Flora of Senegal", Berhaut has presented 79 genera and 248 species. Continuing his work, Vanden Berghen has described 98 genera and 282 species in the "Flore illustrée du Sénégal". Whereas, Ba and Noba, from a synthesis of available data on the flora of Senegal, draw up a floristic list made up of 285 species belonging to 93 genera. As for Mugnier, he used the notes left by Berhaut and reveals the presence of 72 genera without specifying the number of species. Although this flora is relatively known, the available data sometimes remain incomplete, justifying probably many doubts expressed by the authors about the presence of some species. However, many other reported species from ancient and recent studies have not been taken into account in the studies cited above. This lack of available and relevant information constitutes an obstacle to the precise evaluation, characterization of the current state of the Poaceae family diversity in Senegal.

This paper provides a checklist of new grasses encountered in Senegal with an updated nomenclature of species. Localities of their occurrence as well as biogeographical affinity and biological types are also given.

\section{Materials and Methods}

The literature search focused on scientific documentation (Berhaut, 1967; Vanden Berghen, 1988; Ba \& Noba, 2001; Mugnier, 2008). Additional information is obtained from local herbaria (Dakar and IFAN) and from the online database Global Biodiversity Information Facility (GBIF). Internet searches were conducted and search terms used included "species", "flora" "diversity", "weeds", "Senegal", combined with terms representing the name of species, which made it possible to consult other databases and scientific publications (Lebrun, 1969; Poilecot, 1995, 1999; Bassene et al., 2014) classified as "other sources". All species names have been verified using Lebrun \& Stork's work (1991) and online databases such as the 
"Conservatoire et Jardin botaniques de la Ville de Genève" and the "Plants of the World online".

All the data obtained were entered on an Excel spreadsheet. The basic file included the following headings: genera, species, biological types, flora of Senegal, illustrated flora of Senegal, new flora of Senegal, GBIF Database, other sources, geographical distribution in Africa, geographical distribution in the world, localities and voucher specimen number or author(s) or publisher. From the global list of compiled species, a sorting was carried out, retaining only those not mentioned in the different flora. The precise localities of some species were known from the projection of the geographic coordinates on the administrative map of Senegal using QGIS software version 3.8.1. The analysis of the floristic composition was carried out from the taxonomic, chorological spectra and biological types defined by (Raunkiaer, 1934).

\section{Results and Discussion}

The present study results 24 species of Poaceae family which were found new addition to Flora of Senegal (Table 1). These species are distributed in 15 genera of which the most represented is Sporobolus with 5 species. Genera such as Digitaria, Eragrostis, Perotis, Setaria, and Trichanthecium include 2 species each whereas Aristida, Chloris, Cymbopogon, Enteropogon, Leptochloa, Oryza, Panicum, Schizachyrium, Urochloa represented with single species each (Figure 1). Species are found in all climatic zones in Senegal (Figure 2). With regard to the nomenclature of species, some names have evolved since their determination. First, this is the case of Crypsis compacta (synonymous with Crypsis vaginiflora) which becomes Sporobolus niliacus. In the new illustrated Flora from Senegal, Mugnier mistakenly considers the latter as a synonym of Crypsis schoenoides. Secondly, it is the case of 2 species of the genus Panicum (P. glaucocladum and P. strictissimum) currently called Trichanthecium glaucocladum and $T$. stictissimum respectively. This also concerns Urochloa leersioides, the current name accepted of Brachiaria leersioides. It is quite surprising to note that the majority of the species studied have been collected for decades. In addition, some of them were collected by Berhaut or Vanden Berghen. It is highly plausible that the exact names of species were not determined at that time. Whoever the collectors may be, the species are mostly encountered either in the south of the country known for its significant biological diversity (MEPN, 2010), or in protected areas which are environments conducive to the maintenance of biological diversity and ecological processes essential to life. Although Senegal is one of the most prospected countries in Africa (Lebrun, 1973; Camara et al., 2019), these conserved environments and this southern part deserve to be further explored just like the eastern regions of Senegal which present a great floristic diversity (Diop et al., 2012) with potentially 
1,184 species out of the 2,500 known species of the flora of Senegal (Berhaut,

1967; Ba \& Noba, 2001; Camara et al., 2019).

Table 1: List of Poaceae species newly found in Senegal.

\begin{tabular}{|c|c|c|c|c|c|}
\hline Species (updated names) & Habit & GD & GDW & Locality & $\begin{array}{l}\text { Voucher } \\
\text { specimen/ } \\
\text { Author }\end{array}$ \\
\hline Aristida recta Franch. & $\mathrm{He}$ & $\begin{array}{l}\text { GC- } \\
\text { SZ }\end{array}$ & Af & Kaolack & $\begin{array}{c}\text { Valenza } \\
1548 \\
\end{array}$ \\
\hline Chloris pycnothrix Trin. & $\mathrm{Th}$ & $\begin{array}{l}\text { GC- } \\
\text { SZ }\end{array}$ & Asa & $\begin{array}{l}\text { Niokolo Koba } \\
\text { National Park }\end{array}$ & Dieye 1237 \\
\hline $\begin{array}{l}\text { Cymbopogon caesius (Hook. } \\
\text { \& Arn.) Stapf }\end{array}$ & $\mathrm{He}$ & SZ & As & $\begin{array}{l}\text { West of Gueumbeul } \\
\text { Special Wildlife } \\
\text { Reserve }\end{array}$ & Boudet 609 \\
\hline Digitaria pearsonii Stapf & $\mathrm{Ge}$ & SZ & Af & Near Djender Guedj & Sall 22448 \\
\hline $\begin{array}{l}\text { Digitaria sanguinalis (L.) } \\
\text { Scop. }\end{array}$ & Th & $\begin{array}{l}\text { Sah } \\
\text { sind- } \\
\text { Med }\end{array}$ & As & Hann & $\begin{array}{c}\text { Berhaut } \\
2824\end{array}$ \\
\hline $\begin{array}{l}\text { Enteropogon monostachyos } \\
\text { (Vahl) K.Schum. }\end{array}$ & $\mathrm{He}$ & SZ & As & Kafountine & $\begin{array}{c}\text { Compaore } \\
126 \\
\end{array}$ \\
\hline Eragrostis lehmanniana Nees & $\mathrm{He}$ & SZ & Af & Dakar & - \\
\hline $\begin{array}{l}\text { Eragrostis viscosa (Retz.) } \\
\text { Trin. }\end{array}$ & Th & SZ & As & Near Cap Skirring & Gaston 921 \\
\hline $\begin{array}{l}\text { Leptochloa } \\
\text { anisopoda (B.L.Rob.) } \\
\text { P.M.Peterson } \\
\end{array}$ & $\mathrm{Th}$ & SZ & $\mathrm{Aa}$ & Linguere & Diop 22467 \\
\hline Oryza latifolia Desv. & $\mathrm{Ge}$ & SZ & $\mathrm{Aa}$ & Kedougou & $\begin{array}{l}\text { Goudiaby } \\
\text { (1993) }\end{array}$ \\
\hline Panicum hirtum Lam. & Th & SZ & Af & Casamance & $\begin{array}{c}\text { Berhaut } \\
6410\end{array}$ \\
\hline Perotis hildebrandtii $\mathrm{Mez}$ & Th & SZ & Af & $\begin{array}{l}\text { Boal. Between } \\
\text { Bignona and } \\
\text { Ziguinchor } \\
\end{array}$ & $\begin{array}{l}\text { BCMD } \\
\text { SS651 }\end{array}$ \\
\hline Perotis patens Gand. & Th & $\mathrm{SZ}$ & $\mathrm{M}$ & Mlomp & $\begin{array}{l}\text { Bassene } e t \\
\text { al. }(2014)\end{array}$ \\
\hline $\begin{array}{l}\text { Schizachyrium } \\
\text { maclaudii (Jacq.-Fél.) } \\
\text { S.T.Blake }\end{array}$ & $\mathrm{Th}$ & $\begin{array}{l}\text { GC- } \\
\text { SZ }\end{array}$ & Af & Djifanghor & $\begin{array}{l}\text { CIAT } \\
96718\end{array}$ \\
\hline Setaria italica (L.) P.Beauv. & $\mathrm{Th}$ & $\begin{array}{l}\text { SZ- } \\
\text { Sah } \\
\text { sind }\end{array}$ & As & $\begin{array}{c}\text { Fathala Forest, } \\
\text { Saloum National } \\
\text { Park }\end{array}$ & $\begin{array}{c}\text { Vanden } \\
\text { Berghen } \\
10389 \\
\end{array}$ \\
\hline Setaria longiseta P.Beauv. & $\mathrm{He}$ & $\begin{array}{l}\text { GC- } \\
\text { SZ }\end{array}$ & Af & $\begin{array}{l}\text { Niokolo Koba } \\
\text { National Park }\end{array}$ & Dieye 1297 \\
\hline $\begin{array}{l}\text { Sporobolus aculeatus (L.) } \\
\text { P.M.Peterson }\end{array}$ & Th & $\begin{array}{l}\text { Sah } \\
\text { sind- } \\
\text { Med } \\
\end{array}$ & As & Tambacounda & $\begin{array}{l}\text { Madsen } \\
(1995)\end{array}$ \\
\hline $\begin{array}{l}\text { Sporobolus africanus (Poir.) } \\
\text { Robyns \& Tournay }\end{array}$ & $\mathrm{He}$ & $\mathrm{SZ}$ & As & Near Dioulakolon & $\begin{array}{l}\text { CIAT } \\
20043 \\
\end{array}$ \\
\hline Sporobolus infirmus $\mathrm{Mez}$ & Th & $\begin{array}{l}\text { GC- } \\
\text { SZ }\end{array}$ & Af & $\begin{array}{l}\text { Km 5-18 along road } \\
\text { Dindefelo }\end{array}$ & $\begin{array}{l}\text { Valenza } \\
2078\end{array}$ \\
\hline
\end{tabular}




\begin{tabular}{|c|c|c|c|c|c|}
\hline \multicolumn{2}{|l|}{$\begin{array}{l}\text { Sporobolus niliacus (Fig. \& } \\
\text { De Not.) P.M.Peterson }\end{array}$} & Th & SZ & As & 一 \\
\hline \multicolumn{2}{|l|}{$\begin{array}{l}\text { Sporobolus pilifer (Trin.) } \\
\text { Kunth }\end{array}$} & Th & $\begin{array}{l}\text { GC- } \\
\text { SZ }\end{array}$ & $\mathrm{Pt}$ & $\begin{array}{l}\text { District of Agnam } \\
\text { Civol }\end{array}$ \\
\hline \multicolumn{2}{|c|}{$\begin{array}{l}\text { Trichanthecium glaucocladum } \\
\text { (C.E.Hubb.) Zuloaga \& } \\
\text { Morrone }\end{array}$} & Th & $\mathrm{GC}$ & Af & Kedougou \\
\hline \multicolumn{2}{|c|}{$\begin{array}{l}\text { Trichanthecium strictissimum } \\
\text { (Afzel. ex Sw.) Zuloaga \& } \\
\text { Morrone }\end{array}$} & $\mathrm{He}$ & $\begin{array}{l}\text { GC- } \\
\text { SZ }\end{array}$ & Af & - \\
\hline \multicolumn{3}{|c|}{$\begin{array}{l}\text { Urochloa leersioides (Hochst.) } \\
\text { A.M.Torres \& C.M.Morton }\end{array}$} & $\begin{array}{l}\text { SZ- } \\
\text { Sah } \\
\text { sind }\end{array}$ & Af & $\begin{array}{l}\text { Bouyouyou-Bofa } \\
\text { Bayot }\end{array}$ \\
\hline \multicolumn{6}{|c|}{$\begin{array}{l}\text { Legend: Habit: } \mathrm{Ge}=\text { Geophyte; } \mathrm{He}=\mathrm{Hemicryptophyte} \text {; } \mathrm{Th}=\text { therophyte; } \\
\text { Geographical Distribution in the World: } \mathrm{Aa}=\text { Afro-American; } \mathrm{Af}=\text { African } \\
\text { Asian; Asa = Afro-Asian and American; } \mathrm{M}=\text { Afro-Malagasy; } \mathrm{Pt}=\text { Pantropica } \\
\text { Geographical Distribution in Africa: } \mathrm{GC}=\text { Guineo-Congolese; GC-SZ = } \\
\text { Congolese-Sudano-Zambezian; Sah sind-Med = Saharo-Sindian-Mediterra } \\
\text { Sudano-Zambezian; SZ-Sah sind = Sudano-Zambezian-Saharo-Sind }\end{array}$} \\
\hline \multirow[t]{2}{*}{$\begin{array}{r}\text { Aristida } \\
\text { Chloris } \\
\text { Cymbopogon } \\
\text { Digitaria } \\
\text { Enteropogon } \\
\text { Eragrostis } \\
\text { Leptochloa } \\
\text { Oryza } \\
\text { Panicum } \\
\text { Perotis } \\
\text { Schizachyrium } \\
\text { Setaria } \\
\text { Sporobolus } \\
\text { Trichanthecium } \\
\text { Urochloa }\end{array}$} & $=$ & & & & \\
\hline & & & & & \\
\hline
\end{tabular}

Figure 1: Number of species encountered by genus. 


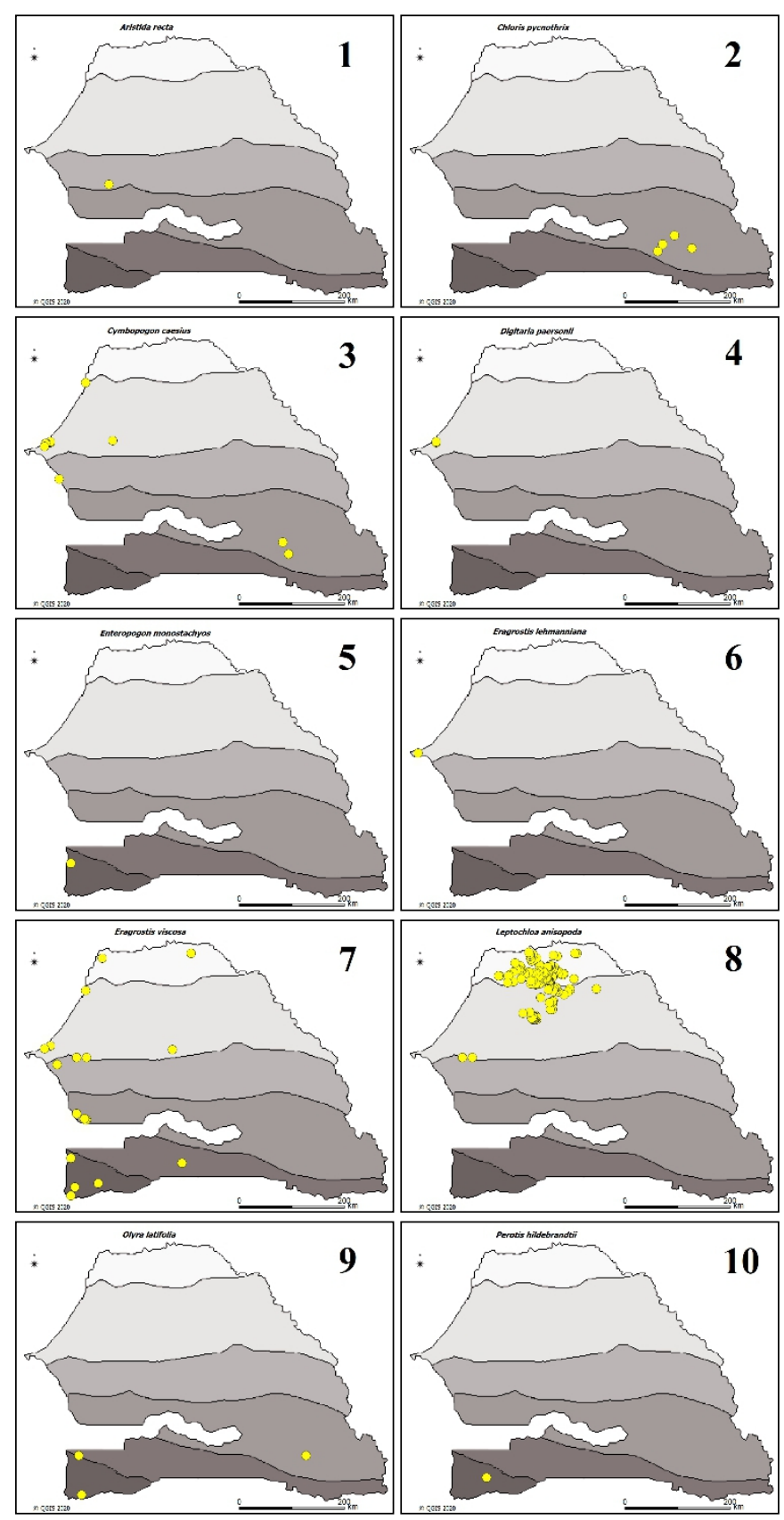




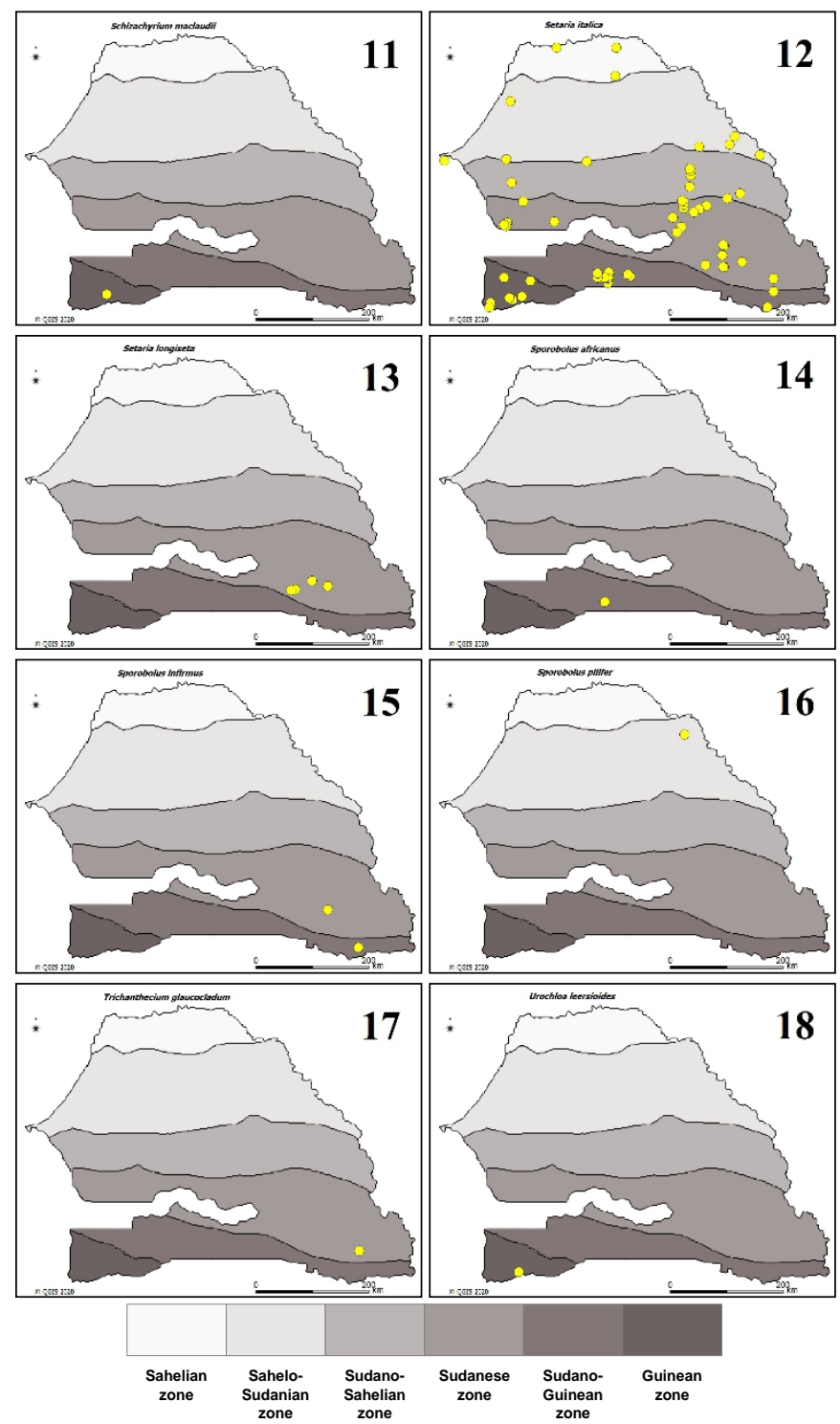

Figure 2: Map showing the distribution of selected new records from Senegal.

1. Aristida recta; 2. Chloris pycnothrix; 3. Cymbopogon caesius; 4. Digitaria pearsonii; 5. Enteropogon monostachyos; 6. Eragrostis lehmanniana; 7. Eragrostis viscosa; 8. Leptochloa anisopoda; 9. Oryza latifolia; 10. Perotis hildebrandtii; 11. Schizachyrium maclaudii; 12. Setaria italica; 13. Setaria longiseta; 14. Sporobolus africanus; 15. Sporobolus infirmus; 16. Sporobolus pilifer; 17. Trichanthecium glaucocladum; 18. Urochloa leersioides.

The distribution of species based on their biogeographical affinities has been described at the global and continental levels. Figure 3 shows the importance of African species, more adapted to the bioclimatic conditions of the environment (Noba et al., 2004; Bassene et al., 2014), which occupy 
almost half (45.83\%). Among the multicontinental taxa, a large proportion (33.33\%) is Afro-Asiatic in origin followed by Afro-American species $(8.33 \%)$ and then African-American, American and Afro-Malagasy represented with only one species each $(4.17 \%)$. The chorological spectrum also highlights the tropical nature of this new grass flora. Indeed, the analysis of the chorological affinities of the different species at continental level shows a clear dominance of the Sudano-Zambesian species which represent half $(50 \%)$ of the total (Figure 4). Then, the Guinean-Congolese-SudanoZambesian species (29.17\%) follow, forming with the first cited about $80 \%$ of the species. The significant proportions of these species are to be compared to the geographic position of the country straddling the Guinean and Sudanian climatic domains (MEDD, 2015).

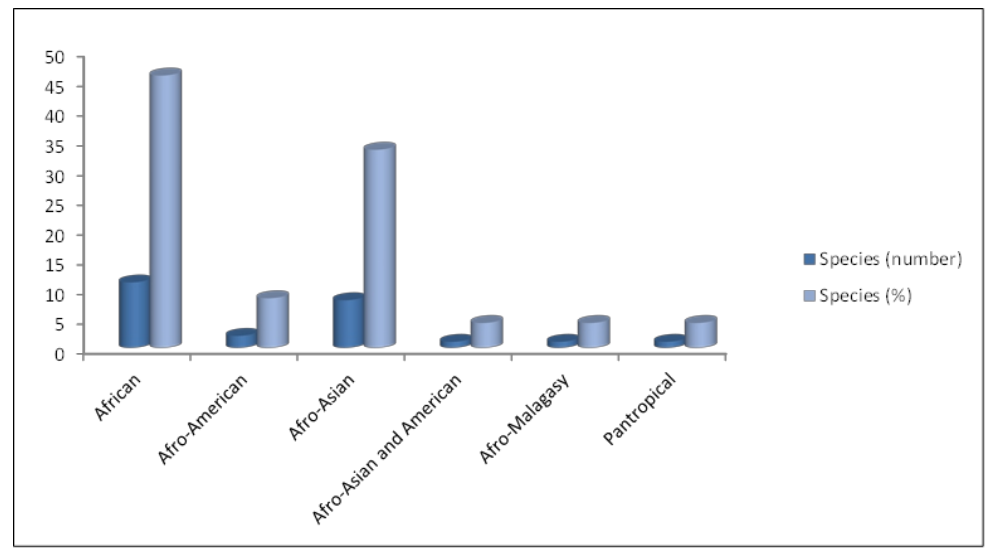

Figure 3: Chorological types spectrum at global level showing distribution of species by biogeographical affinities in the world.

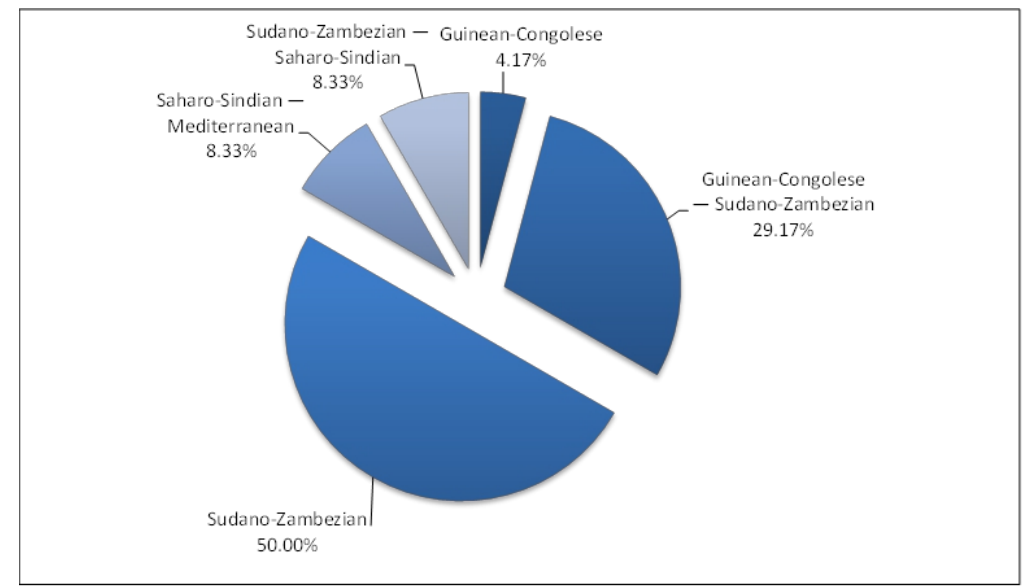

Figure 4: Chorological types spectrum at continent level showing distribution of species by biogeographical affinities in Africa. 
Biological types of the new recorded grass flora based on the life forms are prepared by following Raunkiaer (1934). Figure 5 shows a predominance of therophytes $(62.50 \%)$. The other biological types are represented by hemicryptophytes $(29.17 \%)$ and geophytes $(8.33 \%)$, by far the least important. The importance of therophytes would be a characteristic of arid zones such as Senegal, as is the predominance of the Poaceae family in West Africa (Oumorou \& Lejoly, 2003; Folega et al., 2018).

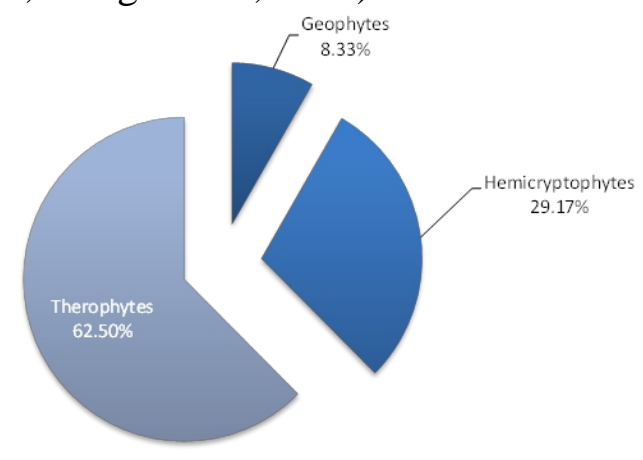

Figure 5: Distribution of species by biological types.

\section{Conclusion}

Based on the present study, the specific richness of Senegalese grass flora is much greater than the number of species actually described. Taking into account this new list of 24 species is an important step in updating the occurrence data for species of the overall grass flora. Indeed, up till today, approximately $35 \%$ of the species described in the flora of Senegal have been estimated not subject of a revision since 1967. Added to the fact that the country appears as a center of endemism for western herbaceous plants and to the current biodiversity regression through human action, it is still urgent to preserve these natural resources. This will necessarily require consistent inventory and monitoring programs taking into account the range and size of species populations.

\section{Acknowledgements}

The authors are grateful to the Curators of the Herbaria DAKAR and IFAN of the University Cheikh Anta Diop of Dakar by providing plant material.

\section{Conflict of interest}

Authors do not have any conflict of interests to declare.

\section{References:}

1. Ba, A. T. \& Noba, K. (2001). Flore et biodiversité végétale au Sénégal. Science et Changements Planétaires/Sécheresse, 12(3), 149-155. 
https://www.jle.com/fr/revues/sec/e-

docs/flore_et_biodiversite_vegetale_au_senegal230110/article.phtml

2. Bassene, C., Mbaye, M. S., Camara, A. A., Kane, A., Gueye, M., Sylla, S. N. \& Noba, K. (2014). Flore des systèmes agropastoraux de la Basse Casamance (Sénégal): cas de la communauté rurale de Mlomp. International Journal of Biological and Chemical Sciences, 8(5), 22582273). http://doi.org/10.4314/ijbcs.v8i5.28

3. Berhaut, J. (1967). Flore du Sénégal. 2ème édition. Dakar (Sénégal): Editions Clairafrique.

4. Camara, A. A., Mbaye, M. S., Bassene, C., Sambou, H., Sarr, M., Ka, S. L., Ngom, A., Mballo, R., Ngom, P. I., Diop, D. \& Noba, K. (2019). Une nouvelle espèce du genre Indigofera L. Fabaceae Lindl. (Leguminosae Juss.) Faboideae pour la flore du Sénégal. International Journal of Biological and Chemical Sciences, 13(1), 399-410). https://doi.org/10.4314/ijbcs.v13i1.31

5. Diop, D., Mbaye, M. S., Kane, A., Sambou, B., Noba, K., Bâ, A. T. \& Nongonierma, A. (2012). Une nouvelle espèce du genre Ficus L. (Moraceae L.) dans la flore du Sénégal. Bulletin IFAN Ch. A. Diop, Dakar T. LIII, 1, 89-98.

6. Folega, F., Wala, K., Woegan, A. Y., Kanda, M., Dourma, M., Batawila, K. \& Akpagana, K. (2018). Flore et communautés végétales des inselbergs du Sud-Est du Togo. Physio-Géo, 12, 1-21. https://doi.org/10.4000/physio-geo.5672

7. Lebrun, J. P. \& Stork, A. (1991). Enumération des Plantes à Fleurs d'Afrique Tropicale. Vol I, II, III, IV. Genève: Edition des conservatoires et jardin botaniques de la ville de Genève.

8. Lebrun, J. P. (1969). Nouvelle contribution à la connaissance de la flore de la République du Sénégal et bibliographie botanique sénégalaise 1941-1969. Bulletin de la Société Botanique de France, 116, 249-277. https://doi.org/10.1080/00378941.1969.10838665

9. Lebrun, J. P. (1973). Enumération des plantes vasculaires du Sénégal. Etude Botanique N², I.E.M.V.T. 10. France : rue Pierre Curie 94700 Maison Alfort Val-De-Marne.

10. Mugnier, J. (2008). Nouvelle flore du Sénégal et des régions voisines.

11. Ngom, A., Mbaye, M. S., Barnaud, A., Gueye, M. C., Camara, A. A., Gueye, M., Diop, B. M. \& Noba, K. (2019). Ecological distribution, diversity and use of the genus Digitaria Haller (Poaceae) in Senegal. International Journal of Biodiversity and Conservation, 11(1), 8-17. https://doi.org/10.5897/IJBC2017.1150

12. Noba, K., Bâ, A. T., Caussanel, J. P., Mbaye, M. S. \& Barralis, G. (2004). Flore adventice des cultures vivrières dans le sud du Bassin 
arachidier (Sénégal). Webbia, 59(2), 293-308. https://doi.org/10.1080/00837792.2004.10670774

13. Oumorou, M. \& Lejoly, J. (2003). Écologie, flore et végétation de l'inselberg Sobakperou (Nord-Bénin). Acta Botanica Gallica, 150(1), 65-84. https://doi.org/10.1080/12538078.2003.10515987

14. Poilecot, P. (1995). Les Poaceae de la Côte d'Ivoire. Mémoires de botanique systématique. Boissiera vol. 50. Genève: Conservatoire et Jardin Botanique de la Ville de Genève.

15. Poilecot, P. (1999). Les Poaceae du Niger. Mémoires de botanique systématique. Boissiera vol. 56. Genève: Conservatoire et Jardin Botanique de la Ville de Genève.

16. Raunkiaer, C. (1934). The life forms of plants and statistical Plants Geography. London: Oxford University Press.

17. Sénégal. Ministère de l'Environnement et de la Protection de la Nature. (1997). Rapport National Biodiversité. Retrieved from: https://www.cbd.int/doc/world/sn/sn-nr-01-fr.pdf

18. Sénégal. Ministère de l'Environnement et de la Protection de la Nature. (2010). Quatrième Rapport National sur la mise en œuvre de la Convention sur Diversité Biologique. Retrieved from: https://www.cbd.int/doc/world/sn/sn-nr-04-fr.pdf

19. Sénégal. Ministère de l'Environnement et du Développement Durable. (2015). Stratégie nationale et plan national d'actions pour la diversité. Retrieved from: http://extwprlegs1.fao.org/docs/pdf/sen166823.pdf

20. Vanden Berghen, C. (1988). Flore illustrée du Sénégal. Monocotylédones et Ptéridophytes. Tome 9. Monocotylédones: Agavacées à Orchidacées. Dakar: Gouvernement du Sénégal. 